
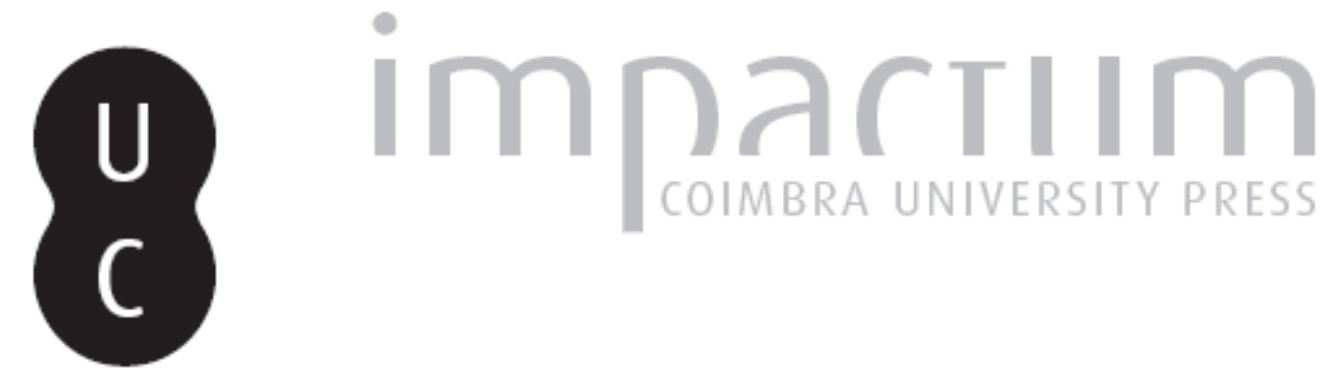

\title{
Estratégias discursivas em Plutarco: vida de Fócion
}

\section{Autor(es): $\quad$ Fialho, Maria do Céu}

Publicado por: Centro de História da Universidade de Lisboa

URL persistente:

URI:http://hdl.handle.net/10316.2/23754

DOI:

DOI:http://dx.doi.org/10.14195/0871-9527_20_25

Accessed : $\quad$ 26-Apr-2023 12:56:22

A navegação consulta e descarregamento dos títulos inseridos nas Bibliotecas Digitais UC Digitalis, UC Pombalina e UC Impactum, pressupõem a aceitação plena e sem reservas dos Termos e Condições de Uso destas Bibliotecas Digitais, disponíveis em https://digitalis.uc.pt/pt-pt/termos.

Conforme exposto nos referidos Termos e Condições de Uso, o descarregamento de títulos de acesso restrito requer uma licença válida de autorização devendo o utilizador aceder ao(s) documento(s) a partir de um endereço de IP da instituição detentora da supramencionada licença.

Ao utilizador é apenas permitido o descarregamento para uso pessoal, pelo que o emprego do(s) título(s) descarregado(s) para outro fim, designadamente comercial, carece de autorização do respetivo autor ou editor da obra.

Na medida em que todas as obras da UC Digitalis se encontram protegidas pelo Código do Direito de Autor e Direitos Conexos e demais legislação aplicável, toda a cópia, parcial ou total, deste documento, nos casos em que é legalmente admitida, deverá conter ou fazer-se acompanhar por este aviso.

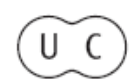




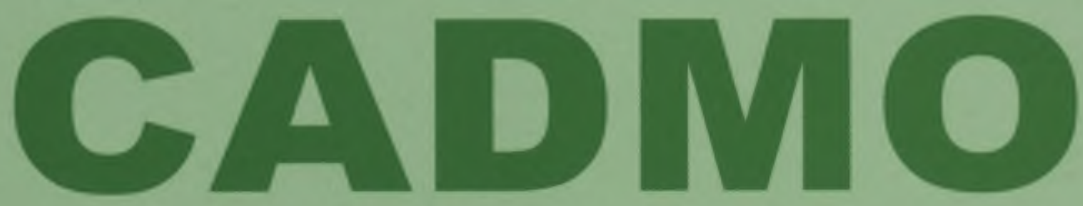

Revista de História Antiga

\author{
Centro de História \\ da Universidade de Lisboa
}

\title{
20
}

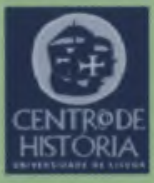

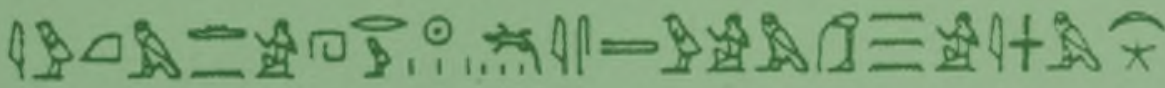



MHNIN AEI $\Delta$ E $\Theta E A ~ \Pi H \Lambda H I A \triangle E \Omega$ 


\title{
ESTRATÉGIAS DISCURSIVAS EM PLUTARCO, VIDA DE FÓCION ${ }^{(1)}$
}

\author{
MARIA DO CÉU FIALHO \\ Universidade de Coimbra \\ mcfialhofluc@gmail.com
}

\section{Resumo}

A antecipação da synkrisis no par de Vidas Fócion/Catão é conjugada, por Plutarco, com uma estatégia discursiva específica pela qual o autor vai sancionando a sua preferência por Fócion, através de pistas hermenêuticas que conduzem à apreensão e compreensão do macrotexto. Essas pistas ganham consistência numa teia de referências hipotextuais que levam à apreciação diferenciada de Fócion e Catão. Percebe-se como o modelo de Sócrates é vivido espontaneamente por Fócion e assimilado artificialmente por Catão. O mesmo acontece com modelos de heroicidade trágica. O universo de referências literárias e de utilização de imagens contribui para essa complexa teia de alusões que dá vida, adequadamente, ao destino e à existência de Fócion no contexto de uma época também ela complexa, conturbada, que leva a interpretações diversas do carácter e da acção do biografado.

Palavras-chave: Fócion; Catão; Sócrates; Atenas no século IV a. C.; Macedónia.

\section{Abstract}

The pair of Lives Phocion/Cato contains an anticipated synkrisis. This anticipation is combined, by Plutarch, with a specific speech strategy. With it the author gives consistency to his preference regarding Phocion, by highlighting the text with hermeneutic clues - they become consistent in the context of 
the net of hipotextual references and lead to the understanding of the macrotext. It is to be seen how far the Socratic model is spontaneously assimilated by Phocion and artificially assimilated by Cato. The same happens in regard to tragic heroic patterns. The universe of literary references and poetic images plays a main role in the complex net of allusions that gives adequately life to Phocion's destiny and existence in an historical period which was by itself so complex and turbulent that it gave place to different and contradictory interpretations of Phocion's ethos and politic action.

Key-words: Phocion; Cato; Socrates; Athens, IV B.C.; Macedon.

A existência de Fócion, pela sua longevidade, acompanhou o turbulento século IV a. C. numa Atenas enfraquecida e dividida, e em franca decadência política e profunda crise identitária. Desgastada pela longa guerra civil do século anterior, que the custou a humilhação da derrota e a perda de muitos homens, desgastada igualmente pela experiência da tirania, reinstaurada na cidade, Atenas confronta-se, em meados do século IV, com séria instabilidade política. Dela, são flagrante testemunho os processos políticos sucessivos, movidos a figuras públicas e a estrategos, até à chamada Guerra Social. A esta paisagem interna da cidade corresponde, na política externa, um avolumar de ressentimentos, já que, no contexto da tentativa de constituição de uma segunda Liga, Atenas manifestou o seu desrespeito para com cidades aliadas, com quem havia estabelecido acordos e a quem havia prometido garantias. Simultaneamente, incrementava o seu expansionismo colonialista, com a fundação de cleruquias, como em Samos e Potideia, entre outros lugares ${ }^{(2)}$. Entretanto, toma corpo nova ameaça externa, desta vez vinda do norte, da longínqua Macedónia em que Filipe, dotado de visão estratégica militar e de fortes ambições expansionistas, vai fortalecendo o seu poder e o seu exército, pois sente chegada a hora de submeter ao seu domínio uma Hélade fragmentada. Esta ameaça vem a tornar-se realidade e, após a batalha de Queroneia, em 338 a. C., em que Atenienses e Tebanos saem vencidos, Atenas perde a liberdade, sob o domínio dos senhores da Macedónia, então construtores de um império.

Neste quadro de instabilidade se recorta a figura de Fócion, como um daqueles exemplos de conduta pautada pela dikaiosyne e constantia de carácter e de acção que nos ficaram da Antiguidade. Irrepreensível na sua conduta política e pessoal, determinada pelos 
interesses de uma Atenas que o teme e o respeita, Fócion foi condenado à morte pela ingestão de cicuta em 318 a. C. por essa mesma cidade, ou melhor, por uma populaça manobrada por representantes do poder macedónio, que nada tinha a ver com o exercício da mais genuína democracia dos longínquos tempos do séc. V. Tinha então oitenta e quatro anos. Pouco tempo depois da sua morte, esta converte-se num incómodo espinho de sentimento de culpa e má consciência da cidade.

Diferentemente de muitos dos outros heróis biografados por Plutarco, Fócion não representa, por sinédoque, o espírito e os destinos da comunidade política do seu tempo - ele é, pelo contrário, um homem que vive os problemas da sua época, que luta contra os males dela na medida do possível, que nela quer intervir e inflectir tendências do comportamento colectivo no que diz respeito à ética política. O seu esforço é contínuo, enérgico, mas vão. Há lutas que trava com a plena consciência de estar rodeado de traidores. Plutarco (Phoc. 1. 4) vê, nesse destino, o fruto de uma luta desigual com a Tyche ${ }^{(3)}$.

Esta sua dissonância com o comportamento mais comum na cidade, na sua época, leva Plutarco a escolher como seu par um romano que se assume como admirador do modelo de Sócrates e adepto fervoroso do estoicismo em Roma: Catão de Útica. Ainda que a aproximação tenha os seus limites e dificuldades, como o próprio Plutarco o reconhece, nas vidas de ambos assistimos a uma luta hercúlea e, de um modo geral, inglória de dois homens contra o curso dos acontecimentos, contra o espírito reinante nessa mesma época ${ }^{(4)}$, como se de uma luta contra uma Tyche peculiar e particularmente poderosa se tratasse. E quase a venceram, no eco que de si mesmo deixaram, logo após a sua morte. A presença do modelo socrático em Fócion, através do elo de conexão que foi Platão e a Academia, é, todavia, natural, não exibido e associa-se a um estoicismo moderado que pauta a conduta pessoal e pública do Ateniense.

Pertence este par de Vidas a um pequeno conjunto de quatro pares sem synkrisis final(5). Verificamos, no entanto, que o proémio das Vitae de Fócion e de Catão contém uma espécie de synkrisis antecipada onde o autor justifica as razões da escolha da aproximação entre ambos.

São perceptíveis, à partida, sinais da preferência de Plutarco por Fócion: a archaiotropia de Catão surge em tempos de costumes corruptos e depravados e, por isso mesmo, por ser única, traz-lhe doxan... megalen kai kleos (3.3). A sua virtude e nobreza não traduzem uma 
adequação histórica ao seu tempo - a dureza e a dimensão da arete de Catão é asymetron e alheia às necessidades da sua época: falta- Ihe o sentido do kairos, como Plutarco afirma num passo marcado por referências da linguagem musical ao serviço do discurso filosófico platónico e órfico-pitagórico e político filosófico do De República ciceroniano (2. 5).

É neste desajustamento em relação ao contexto histórico respectivo, que se traduz no próprio modo de intervenção de Catão nos acontecimentos, que se separam o herói romano do herói grego. Catão, de acordo com Plutarco, viveu como se estivesse na Politeia platónica, não entre a escória de Rómulo (3. 1), e esse foi o motivo da sua $\operatorname{derrota}^{(6)}$.

Esta espécie de antecipação da synkrisis não parece significar apenas um mero processo de variatio na disposição dos elementos do discurso biográfico: pelo contrário, ela tem implicações muito concretas na relação que o leitor estabelece com o texto e no modo como o interpreta e o entende, assim como na sua apreensão do perfil dos dois políticos ${ }^{(7)}$.

O juízo comparativo antecipado, assim como a visão global de cada uma das Vitae, leva o leitor a procurar no percurso existencial de cada biografado uma espécie de confirmação daquilo que se apresentou antecipadamente. O itinerário dessa confirmação exige uma estratégia global, que Plutarco assume. Ele marca as referidas Vidas com sinais de cariz diverso e em diversos níveis do discurso, como uma espécie de Wegweiser que ordenam a sua leitura compreensiva como um macrotexto.

Assim, ao falarmos da questão da interpretação de texto nas $\mathrm{Vi-}$ das de Fócion e de Catão teremos de partir do princípio de que ela implica o reconhecimento de níveis diversos na urdidura do texto.

O primeiro e mais evidente será o do produto final: o macrotexto que se oferece a uma leitura interpretativa, feita sob o signo da comparação e do juízo antecipados, da Vida de Fócion e da Vida de Catão.

O segundo corresponde a um plano diverso, a partir do qual a coerência da leitura do primeiro é construída e assinalada através dos referidos indicadores. Trata-se do nível hipotextual. Verifica-se a existência de um jogo complexo de hipotextos que se cruzam e que ajudam a estabelecer afinidade e contrastes entre Fócion e Catão. Esse efeito deve-se, em primeiro lugar, à utilização de diálogos platónicos centrados nos úitimos momentos da vida de Sócrates, com particular destaque para Apologia e Fédon, ainda que se possam identificar 
referências de Górgias e Banquete. Mais ténue será o efeito da utilização hipotextual da tragédia sofocliana ou das Histórias de Heródoto. O recurso que Plutarco faz destas fontes visa sugerir, ao espírito do leitor, analogias, simetrias e dissimetrias que neste operam e vincam impressões, estimulam a sensibilidade e a imaginação, ao serviço de um efeito cognitivo atingido no plano do sugerido, do emocional e estético, tal como actua a conotação, própria do texto literário, por diferença em relação ao discurso assertivo, do âmbito do denotativo.

Veja-se, pois, como Plutarco introduz em ambas as Vidas o modelo da figura de Sócrates e como o momento específico de Sócrates perante a morte subjaz ao itinerário comparativo Fócion/Catão. Curiosamente, quanto mais consciente e deliberadamente assumida e ostentada pelos biografados é essa aproximação ao modelo socrático - pelo menos através da perspectiva de Plutarco - tanto mais artificial ela se torna. Assim acontece no caso de Catão.

Em ambos os biografados esse modelo é marcado, como acima se referiu, por uma coloração estóica. No entanto, a leitura obsessiva de Fédon para o círculo dos amigos, feita por Catão no contexto da sua última ceia, contrasta com o comportamento posterior. Este apego ao livro e à cultura teórica, dissociados da experiência de vida, são dissonantes com a espontaneidade das reacções na vida real. A explosão de ira de Catão perante o escravo fiel que the não traz a espada chega ao ponto de o agredir fisicamente com brutalidade - 0 que é avesso à constantia animi defendida e cultivada pelos estóicos. A primeira tentativa de suicídio de Catão falha, devido à fraqueza da sua mão, lesionada pela violenta agressão ao escravo e a segunda tentativa, levada a cabo com sucesso, é descrita por Plutarco com um visualismo impressionante, de modo a sugerir a maneira brutal como pôs fim à vida. Assim sugere o autor a dissonância com a morte de Sócrates, imposta pelos seus juízes e levada a cabo com doçura e serenidade. Estamos, pois, perante uma assimilação desfocada de um modelo - o que talvez seja espelho do próprio desajustamento de Catão em relação à sua época (Phoc. 3.1).

A importância do modelo socrático-platónico para Cato Minor é já reconhecida na própria Roma Antiga, como o lembra J. Geiger ${ }^{(8)}$. Este autor e, posteriormente, em análise mais desenvolvida, A. Zadorojnyi ${ }^{(9)}$ apontam e fundamentam a tese da proposta plutarquiana de uma apropriação desvirtuada do modelo grego por parte de Catão. A chave interpretativa encontra-se, essenciaimente, no jogo entre a leitura do Fédon e a última noite da vida do Romano. Zadorojnyi explora a utili- 
zação de um outro hipotexto: o do Ájax de Sófocles ${ }^{(10)}$. De facto, Catão chama pela sua própria espada, perturbado pela ira de saber que Iha ocultaram para impedir o cumprimento do destino que tinha decidido para si mesmo. Quando, finalmente, se encontra na posse dela e pode cumprir os seus desígnios, com ela se identifica, exclamando nun emos eimi (Cato 70.2), numa atitude que recorda o protagonista sofocliano ao dirigir-se às entidades que sente como partes constituintes do seu mundo e do seu próprio destino - sejam elas as trevas ou a espada ${ }^{(11)}$.

De facto, um hipotexto sofocliano não é tão perceptível na Vida de Fócion, já que, por certo, o desajustamento do solitário protagonista sofocliano em relação ao seu próprio mundo não é adequado para sugerir a situação e acção do Ateniense. Penso, no entanto, que nestas duas vidas comparadas Plutarco apelou para a cultura teatral do leitor, de modo a suscitar, na primeira das biografias, a lembrança, ainda que ténue, de um motivo trágico sofocliano a partir de outro ângulo que não aquele que foca directamente o próprio Fócion. Refiro-me à proibição de dar sepultura a Fócion em Atenas, por um gesto de tirania demagógica, e à corajosa atitude da sua segunda mulher (outra não pode ser a leitura do passo(12)). Embora fragilizada, não pela juventude, mas pela sua muita idade, traz para Atenas, para junto do lar doméstico, os restos mortais de Fócion, com um discurso que lhe é posto na boca por Plutarco e que demonstra, ao mesmo tempo, a coragem cívica, os laços de afecto e a devoção matrimonial, assim como o respeito devido aos mortos e aos seus laços com os antepassados. Ela prevê que, num momento de sophrosyne recuperada - talvez pela desdita política - a cidade reconheça ao morto o direito à sepultura (37.5).

É evidente que o leitor antigo, tal como nós, recordava Antígona. A lógica do processo de leitura permite a associação retrospectiva de dados, já que é possível voltar atrás e reler o já lido. Assim, pareceme que o hipotexto de Ájax na Vida de Catão aviva a hipótese da referência cruzada com um esbatido hipotexto de Antígona na Vida de Fócion. É sintomático que Plutarco tenha eventualmente usado este último à volta da relação matrimonial de Fócion e, como se verá, da própria relação da Cidade com o biografado, após a sua morte. A primeira hipótese remete-nos para a valorização dada à relação homem-mulher no casamento pelo polígrafo de Queroneia e ao papel reconhecido à mulher.

Toma, assim, sentido, a citação da Antígona de Sófocles logo no início da Vida de Fócion, quando Plutarco nega razão às palavras de 
Sófocles, postas na boca de Ismena frente a Creonte, em Antígona (vv. 563-564): "Senhor, até o senso inato se dissipa no meio da desdita e a ela cede". Esta astenia da virtude (1.5) em tempos de desdita não a reconhece Plutarco em Fócion. Este não estará do lado de Ismena - e a acção da sua esposa prolongará a evocação implícita do lado de Antígona.

Por esta estratégia acentua Plutarco a divergência entre Fócion e Catão. Os momentos que antecedem a morte deste último são de dureza para com amigos, familiares e escravos e não de doçura e temperança (Cato 68 sqq.), em contraste com o objecto da sua leitura durante a ceia. O que é encenação na vida do Romano, ou apropriação artificial e com contradições em relação ao paradigma de Sócrates, é natural por parte do Grego.

A grande força que põe à prova a coragem, a virtude, mas também a coerência de comportamento em relação à grande referência paradigmática mestre/modelo é a Tyche, factor sempre presente na existência dos biografados, seja ela propícia ou adversa, na luta sem vitória travada contra ela ou no aproveitamento acrítico dos seus favores por parte dos protagonistas. É na reacção frente à Tyche que se revela a verdadeira natureza destes ${ }^{(13)}$.

Particularmente adversa foi a Tyche para Fócion e para Catão, que "quase" a venceram, mas que, num derradeiro momento, por ela foram vencidos e desse modo não viram devidamente reconhecido o seu esforço e a sua arete. Situações de adversidade e de crise política geram nos caracteres íntegros a propensão para o rigor e a severidade que facilmente ferem a multidão.

A diferença entre Fócion e Catão é subtil: historicamente, o tempo do primeiro é de crise sem regresso, o do segundo de crise de fim de época - a República romana tem os seus dias contados, mas à tirania de César suceder-se-á o Império. Plutarco compara Catão a um fruto for a de época (Phoc. 3.2: tois me kath'horan...karpois). Com esta imagem ele predispõe o leitor para estar atento às diferenças existentes para além das afinidades entre ambos.

Essa diferenciação, consolidada, como foi dito, através da percepção da diferente relação com um paradigma comum, visível no jogo de hipotextos, é preparada nos capítulos iniciais de synkrisis antecipada através de duas estratégias combinadas. Refiro-me à utilização explícita de textos de autores, citados ou meramente referidos, como fonte de credibilidade (será o caso de Cícero, por exemplo), ou então de citações de poetas - Sófocles, Ant. 563-564 (Phoc. 1. 3); 
Arquíloco, frg. 1 West (Phoc. 7. 5.); Homero, Od. ${ }^{(14)}$ - como processo de sugestão mais poderoso que a mera enunciação. A estas referências se alia, para reforçar o seu efeito, uma linguagem de notável profusão imagética. É sintomático que essa profusão se condense, essencialmente, nos capítulos iniciais da Vida de Fócion - capítulos que determinam a orientação da leitura, como um prelúdio em que o tema musical se apresenta. Senão veja-se. A citação das palavras de Dêmades em 1.1, que subvertem a tradicional imagem da nau do estado e a usam sob a forma de naufrágio e de destroços de naufrágio (ta nauagia), permite a Plutarco distinguir os dois simpatizantes da causa macedónia - em tempo de crise, versus de naufrágio, Dêmades é ele mesmo um desses destroços. Fócion, em contrapartida, faz frente a esse mesmo naufrágio com inegável arete, embora as tychai adversas da Hélade o tenham privado de glória e reconhecimento.

Esta apresentação da arete mal compreendida de Fócion é justificada pelo azedume e susceptibilidade, em tempos difíceis, da multidão, que não suporta palavras mais duras de políticos incorruptos e rigorosos, pouco interessados em captar as boas graças - a ideia é reforçada por uma comparação extraída da prática médica, a do ardor que o mel provoca nas feridas, ao mesmo tempo que as limpa (2.3), e abonada por uma citação de Homero (Od. 5. 165-166). Plutarco centra, de seguida, a sua atenção no fenómeno de uma Atenas que acolhe mal a franqueza rude mas bem intencionada de Fócion. Agora, a partir do ângulo de perspectiva da cidade, aquele recorre a nova comparação, inspirada no domínio da oftalmologia (2.4) - os olhos doentes encontram conforto na contemplação de cores sombrias e evitam as que possuem brilho e reflectem a luz, tal como uma cidade tomada por uma sorte adversa suporta mal a franqueza e a denúncia dos seus erros.

A complexa comparação que se segue (2. 6-9) apresenta uma disposição inicial de elementos análoga à anterior. É extraída do âmbito da astronomia e virá a desdobrar se numa aproximação à música. O movimento do sol não coincide com o do céu, mas não se the opõe nem o contraria - a sua marcha é oblíqua e curva, possui uma flexibilidade que garante a harmonia universal. Este é o princípio da cedência oportuna que deve reger a prática política de quem enfrenta a vontade popular. O rigor e a dureza sistemáticos, que não conhecem a cedência no tempo próprio nem a doçura (praotes) que cria vínculos de reciprocidade, são um caminho perigoso. A severidade e a bondade representam uma aliança de ritmos similar à do governo divino do universo. 
Estas palavras recordam-nos o Somnium Scipionis e parecem ser tacitamente aplicadas a Fócion e explicitamente a Catão, com a corroboração, para este último, de um passo de Cícero, como foi referido, citado de memória. Mas Catão, dirá Plutarco por uma imagem já citada, assemelha-se a um fruto fora de época. Quanto a Fócion, Plutarco demonstrará, nas anecdotae ilustrativas do seu ethos e da sua praxis, até que ponto ele aliava o rigor e a dureza a uma profunda philanthropia e doçura (praotes) ${ }^{(15)}$, demonstradas até aos últimos momentos da sua vida. Philanthropia é, de resto, uma palavra de ordem na caracterização do Ateniense.

Centro agora a minha atenção na relação entre o macrotexto, com a sua synkrisis antecipada, o jogo hermenêutico que se estabelece entre ele e os hipotextos, reforçado pelo registo poético dos primeiros capítulos. A leitura conduz a uma simpatia prevalecente por Fócion. Dele se diz que foi discípulo de Platão e de Xenócrates. Nunca é dito, nem insinuado, por contraste antecipado em relação a Catão, que Fócion se queira impor como um segundo Socrates platónico. A sua conduta assimila, de acordo com a sua própria natureza educada pelos modelos, os valores morais e a conduta dos modelos escolhidos. Mas isso acontece de modo natural aos olhos dos seus concidadãos.

Fócion, ainda jovem, tem o poder de corrigir, pela sua sobriedade e moderação, os excessos temperamentais do estratego Cábrias. O seu desprendimento dos bens materiais era patente no próprio estilo de vida quase miserável que levava com sua mulher, ainda que, com toda a probabilidade, the não faltassem meios ${ }^{(16)}-0$ que the dava a credibilidade política de um homem coerente e desinteressado na sua acção. Era sabido, segundo Plutarco (Phoc. 8.1) que a sua linha de conduta política se orientava pelos valores da paz e da tranquilidade (eirenen kai hesychian). Ora tais conceitos assentam na harmonia universal mencionada em 2.9. Vai assim o leitor percebendo que a crítica feita no preâmbulo à intransigência e dureza atinge muito mais Catão que Fócion, cujo ethos é qualificado em 5.1 como prosenestatos e philanthropotatos: o que a sua expressão de rosto pouco sociável e austera não deixam adivinhar. A descrição de Sócrates, nos diálogos platónicos, com o seu aspecto descuidado e o seu rosto de sátiro, engana também ela, pela aparência, já que a sua harmonia de alma e a sua força para conduzir ao Bem apenas se revelam aos que dele se acercam e com ele convivem. A sua doçura (praotes) e a sua arete são reconhecidas pelo próprio carrasco no Fédon (116c). 
Assim se impõe a personalidade do homem que foi eleito estratego quarenta e cinco vezes numa Atenas de tempo de crise e que recebeu o cognome de "o Bom" (ho chrestos) (10. 4-5). De novo esta contradição entre aspecto, modos e natureza é sublinhada através de uma comparação, desta vez inspirada no domínio da enologia: um vinho pode agradar, ainda que mantenha um travo, enquanto outro, à primeira impressão doce, desagrada depois e mostra-se nocivo.

A resistência de Fócion para suportar os rigores do inverno e os enfrentar com um mínimo de protecção tornou-se proverbial em Atenas. Em campanha militar usava vestes ligeiras e combatia descalço, só usando agasalho debaixo de um frio insuportável (4. 3-4). Como já tem sido notado, esta referência evoca os hábitos de Sócrates mencionados por Platão (e. g. Symp. 220a-b) ${ }^{(17)}$. Esta proximidade com Sócrates, por ser tão natural, não é explicitada por Plutarco. No entanto, o passo remete-nos para a Vida de Catão (44): eleito pretor, Catão apresenta-se na sede do exercício do seu cargo descalço e, muitas vezes, sem túnica. Plutarco censura este comportamento, em que vê uma atitude de desprezo e aviltamento das instituições. Percebe-se que esta atitude representa o distanciamento ostensivo e algo arrogante de Catão em relação à multidão, mas percebe-se também que Plutarco a vê como forçada e desajustada da realidade. O paradigma socrático fica longe e mal assimilado: o que condiz com as conclusões a extrair da ligação dissonante entre a leitura final do Fédon e a cena da espada e das duas tentativas de suicídio.

Segundo Plutarco, a rudeza e a inexorabilidade de Fócion tinham um sentido prático (10.7), tal como a sobriedade enérgica dos seus discursos, que Demóstenes qualificava de "machados»: fazer frente aos seus opositores quando entendia que o bem de Atenas estava em jogo. Não citando Arquíloco, a definição que Fócion dá para o sicofanta Aristogíton - "coxo e cobarde" (10.3) - parece corresponder a um jogo de deturpação crítica do retrato do general ideal do frg. 114 West do poeta de Paros.

As manobras de Poliperconte, enquanto regente macedónio, criaram finalmente condições para eliminar Fócion (32 sqq.). Aparentemente recuperado o antigo regime democrático, por concessão da Macedónia, a Assembleia de Atenas encheu-se com uma multidão de foragidos, de estrangeiros e de gente privada de direitos cívicos por atimia (33.2). Foram esses homens, manipulados pelo Macedónio, quem acusou o ancião Fócion e os seus companheiros de traição à pátria e quem os condenou à morte pela cicuta. Mas o belo discurso de Sócrates aos 
seus juízes atentos, na Apologia de Platão, não tem oportunidade no julgamento de Fócion. Como diz Plutarco "não havia equidade» (33.10). Poliperconte, o dominador estrangeiro, interrompia Fócion sempre que este tomava a palavra, até que Fócion desistiu de falar.

O julgamento encenado denuncia, para os verdadeiros cidadãos, a farsa de democracia que está a ser representada e dá-lhes a consciência do perigo e da degradação político-institucional - do verdadeiro naufrágio da cidade. Plutarco joga com o contraste de situações que rodeiam a morte de Sócrates e a de Fócion: ambos os julgamentos ocorreram no decurso de celebrações religiosas, mas a execução adiada de Sócrates, de acordo com o Críton (43d) ou com o Fédon (58a), até ao regresso da theoria a Atenas, não tem equivalência para o caso de Fócion. $O$ estrangeiro e a multidão sem escrúpulos marcam a execução para o tempo das festividades em honra de Zeus, no mês de Muníquion (37.1). Tal como com o Sócrates do Fédon, é no derradeiro momento de Fócion que, para os que estão com ele, se revela, com toda a clareza, a doçura, serenidade e philanthropia deste homem que não dispunha, sequer, de dinheiro para pagar a cicuta que havia de beber ${ }^{(18)}$.

Sócrates prevê, na Apologia, a dureza do castigo que aqueles que o condenaram receberão no futuro - o julgamento de que serão objecto, mais implacável ainda do que aquele que exercem no momento. Ao calarem a voz incómoda de Sócrates, outras vozes mais incómodas e implacáveis se levantarão contra eles ( $A p .38$ d-e). $\mathrm{O}$ que Sócrates preconiza para o seu caso acontece com Fócion logo após a sua morte - é a própria cidade que é tomada pelo peso da má consciência que perdurará por longo tempo(19). A memória de Fócion será reabilitada. Nesta condenação vê a cidade projectada a imagem da sua própria degradação - de algum modo como Creonte, no final de Antígona: tarde demais, quando a desgraça sobre ele se abateu por deixar os mortos insepultos e condenar inocentes.

Se o modelo de Sócrates ou a analogia com Sócrates ganha vida através da biografia de Fócion através do jogo de hipotextos, Plutarco procede, no entanto, de modo a não fazer coincidir Fócion com a figura de um Sócrates daimonios que a tradição construiu. É, antes de mais, a figura mal compreendida do político sensato, sóbrio, dedicado à cidade e rico em philanthropia que o biógrafo nos quis deixar. Fócion fica como o político que vive os genuínos valores de Atenas e que tenta fazer vingar em Atenas a harmonia política que crê ser possível para a fazer sobreviver do naufrágio. 
O seu esforço foi quase compensado. Dele ficou, entre os Atenienses, o peso de um remorso colectivo e de uma colectiva consciência de culpa. Pouco depois, vai-se impondo na memória a imagem de um homem que se enquadrou no mais genuíno perfil dos grandes chefes incorruptos do passado, de discurso e gesto sóbrio, como o de Sólon ("raras vezes tirava as mãos de dentro da sua capa" 4.3), cuja escala de valores ficou patente no relato do seu encontro com Creso, consagrado no livro I de Heródoto. Análoga diferença de perspectivas entre um Ateniense e um Bárbaro se repete, sobre o modelo soloniano do hipotexto de Heródoto, na incompreensão de Alexandre perante a insensibilidade de Fócion aos tesouros que tenta oferecer-Ihe (17-18).

A trajectória deste homem, que incarnou a sobriedade, os antigos valores da pólis, a dedicação à causa pública ateniense e que, nem sempre, foi compreendido nas suas posições - ele compreendeu que importante era preservar a integridade de Atenas e a sua relativa liberdade, num contexto de degradação da Hélade, definitivamente subjugada pela onda expansionista macedónia e agiu em função dessa percepção - foi captada, no seu todo e no seu sentido por Plutarco. Trata-se de uma trajectória simples num universo complexo, que se desdobra em pontos de vista diversos, correspondentes às sensibilidades e aos interesses diversos a que dá lugar. Talvez por isso mesmo Plutarco tivesse encontrado a forma discursiva adequada para esta Biografia no recurso à complexa trama de sugestões hipotextuais e de imagens que, entretecendo-se a partir do pórtico da Biografia, conduzem a uma sua leitura compreensiva ${ }^{(20)}$. As citações de poetas, que fazem parte da superfície do discurso, conferem consistência e vivacidade à narrativa. Os passos descritivos contribuem, também eles, para essa impressão final que é sublinhada, de modo particular, pelo hipotexto platónico tornado, como se demonstrou, progressivamente mais natural e evidente, à medida que a existência/biografia de Fócion caminha para o seu fim $^{(21)}$.

\section{Notas}

(1) Este texto representa uma versão portuguesa alargada, que envolveu posterior investigação, do texto da conferência que proferi em Setembro de 2007, na Sorbonne, intitulada "The Interplay of Textual References in Plutarch's Life of Phocion".

(2) Como notam J.-M. BLÁSQUEZ, R. LÓPEZ MELERO, J. J. SAYAS, Historia de la Grécia Antigua, Madrid, $1999^{2}$, p. 603 , as causas desta guerra são obscuras, concatenando-se causas remotas a factores de ordem imediata. É sublinhada a importância de Demóstenes 15.3, que refere o factor ressentimento. 
(3) L. A. TRITLE, Phocion the Good, London, New York, Sydney, 1988, pp.8-9. Veja-se, também, A. PÉREZ JIMÉNEZ, "Atitudes de l'hombre frente a la tyche en las Vidas Paralelas de Plutarco" BIEH 7, 1973, 103 sqq. De resto, no caso específico da Vida de Fócion, Plutarco inspirou-se na biografia do estadista e general ateniense consoante Cornélio Nepos a concebe.

(4) S. SWAIN, "Plutarch: Chance, Providence and History" AJPh 110, 1989, 282-283.

(5) As outras são as de Themístocles/Camilo, Pirro/Mário Alexandre/César. Veja-se M. B. TRAPP, "Socrates, the Phaedo, and the Lives of Phocion and Cato the Younger" in: A. PÉREZ JIMÉnEZ,J. GARCÍA LÓPEZ, R. M. AGUILAR (eds.), Plutarco, Platón y Aristóteles. Actas del V Congreso Internacional de la IPS., Madrid, 1999, pp. 487-488.

(6) Plutarco cita Cícero, provavelmente referindo-se a ad Att. 2. 1. 8. A citação deve ter sido feita de memória, já que, como nota B. PERRIN, in: E. H. WAMINGTON (ed.) Plutarch's Lives VIII, Engl. Transl. by PERRIN, London, 1969, p. 150 n. 1, Cícero não cita nominalmente aquele a quem se refere na carta acima indicada.

(7) A função e modalidades de apresentação da synkrisis na biografia, em Plutarco, constituiu objecto de minucioso estudo e sistematização por parte de H. ERBSE, "Die Bedeutung der Synkrisis in den Parallelbiographien Plutarchs" Hermes, 84, 1956, 398-424.

(8) J. GEIGER, "Plato, Plutarch and the Death of Socrates and of Cato" in: A. PÉREZ JIMÉNEZ,J. GARCÍA LÓPEZ, R. M. AGUILAR (eds.), Plutarco, Platón y Aristóteles. Actas del V Congreso Internacional de la IPS., Madrid, 1999, pp. 359-362. Vide também supra n. 6.

(9) “Cato's Suicide in Plutarch" CQ 57, 2007, 216-230.

(10) Ibid. Este recurso fora já apontado brevemente por GEIGER, mas ZADOROJNYI, no citado artigo, aprofunda-o e extrai da sua utilização conclusōes muito pertinentes.

(11) Ao perfil do herói sofocliano, na sua dimensão excepcional, mas também na excepcionalidade das suas emoções e da sua solidão dedicou B. M. W. KNOX o seu consagrado livro The Heroic Temper. Studies in Sophoclean Tragedy, Berkeley, 1964.

(12) Identifico-me com a leitura e as razões apresentadas por R. FLACELIÈRE-.E. CHAMBRY, Plutarque. Vies, t. X, Paris, 1976, p. 162, ao considerar 'Megarikes' uma interpolação.

(13) A. PÉREZ JIMÉNEZ, op. cit. pp. 101-110.

(14) Phoc. 17. 1: Od. 9. 494; Phoc. 2. 3 apresenta uma alusão indirecta a Od. 5. 165-166.

(15) Sobre a importância da philanthropia e da praotes como traços de carácter reflectidos na acção dos biografados vejam-se os dois artigos de H. MARTIN, "The Concept of Philanthropia in Plutarch's Lives" AJPh 82, 1961, 164-175 e "The Concept of Praotês in Plutarch's Lives" GRBS 3, 1960, 65-73. Sobre alguns exemplos de iiustração de philanthropia (todavia não associada a praotes) na vida de Catão de Útica, vide J. PINHEIRO, "O sentido de philanthropia nas Biografias de Cícero, Coriolano e Catão de Útica" in: J. R. FERREIRA, D. LEÃO, M. TROESTER, P. BARATA DIAS (eds.), Symposion and Philanthropia in Plutarch, Coimbra, 2009, pp. 363 sqq. J. de Romilly procedeu ao estudo abrangente e diacrónico da fundamentação e actualização do valor ético da praotes na Cultura Grega: J. de Romilly, La douceur dans la pensée grecque, Paris, 1979.

(16) L. A TRITLE, op. cit., p. 54, sustenta a sua proveniência de uma família abastada e sublinha que a sua própria participação à frente de campanhas militares no estrangeiro the teriam acarretado proventos.

(17) Veja-se, de igual modo, Aristófanes, Nu. 412-428. 
(18) Nota L. A. TRITLE, op. cit. p. 30, que Plutarco recriou uma atmosfera trágica e emocional à volta da descrição da morte de Fócion, a fim de gerar simpatia pelo biografado. $O$ interesse gerado pela sua biografia, segundo TRITLE (pp. 34-35), deve-se ao facto de nele serem visiveis, mais que as qualidades do estratego ou do político concreto, as do político-filósofo, cujas virtudes se prestam, pelo estilo de vida a que correspondem, a construir um paradigma do verdadeiro e ideal politicus.

(19) L. A. TRITLE, op. cit., pp. 30 sqq., conclui, com razão, que este tipo de informação sobre as reacções da colectividade, após a morte de Fócion, provém de fontes escritas.

(20) A acção política de Fócion prestou-se a interpretações várias, desde a de pacifismo à de colaboracionismo com Alexandre. Vide L. A. TRITLE, op. cit. pp. 97-122. Sobre a intervenção de Fócion na vida militar e diplomática da Atenas do seu tempo veja-se $P$. J. RHODES, "The Polis and the Alternatives" in: D. M. LEWIS, J. BOARDMAN, S. HORNBLOWER, M. OSTWALD (eds.), The Cambridge Ancient History, vol. VI, Cambridge, pp. 565-591, J. R. ELLIS, "Macedonian Hegemony created" ibid. p.782 e A. B. BOSWORTH, "Alexander the Great Part 2: Greece and the Conquered Territories" ibid. pp. 848,852 ., O que é certo é que, sendo Fócion proxenos de Alexandre em Atenas representaria os interesses particulares de Alexandre na cidade, sem necessariamente os sobrepor aos desta - os interesses da pólis determinavam o limite dos interesses de qualquer estrangeiro que se fizesse representar pelo seu proxenos. Perspectiva contrária a esta, defendida por TRITLE, op. cit., pp. 115 sqq, é sustentada, entre outros, por C. MOSSÉ, Athens in Decline, , 404-86 b. C., London, Boston, 1973, p. 58. Sobre 'proxenia' vide J. R. FERREIRA, "Próxeno e proxenia" in:D. LEÃO, L. ROSSETTI, M. C. FIALHO (eds.)Nomos. Direito e sociedade na Antiguidade Clássica/Derecho y Sociedade en la Antigüedad Clásica, Coimbra-Madrid, 2004, pp.227-239.

(21) C. ALCALDE MARTÍN, "Rasgos socráticos de la personalidad de Foción en la Vida de Plutarco" in: A. PÉREZ JIMÉNEZ,J. GARCÍA LÓPEZ, R. M. AGUILAR (eds.), Plutarco, Platón y Aristóteles. Actas del V Congreso Internacional de la IPS., Madrid, 1999, pp. 159-171 mostra como esta Vita está organizada em secções bem definidas e como obedece a uma progressiva evidência da analogia entre Fócion e Sócrates. J. GEIGER, «Nepos and plutarch: from Latin to Greek Political Biography" ICS 13, 1988, 256 observa: "The last sentence od the Phocion draws the parallel between the deaths of Phocion and Socrates". 